\title{
GREENHOUSE IRRIGATION WATER DEPTHS IN RELATION TO ROSE STEM AND BUD QUALITIES
}

\author{
Marcos Vinícius Folegatti ${ }^{1 *}$; Edivaldo Casarini'2,3; Flávio Favaro Blanco ${ }^{2,4}$ \\ ${ }^{1}$ Depto. de Engenharia Rural, USP/ESALQ, C.P. 9 - CEP: 13418-900 - Piracicaba, SP. \\ ${ }_{3}^{2}$ Pós-Graduando do Depto. de Engenharia Rural, USP/ESALQ. \\ ${ }^{3}$ Bolsista CAPES. \\ ${ }^{4}$ Bolsista FAPESP. \\ *Autor correspondente <mvfolega@carpa.ciagri.usp.br>
}

\begin{abstract}
The cultivation of roses occupies a special place in the flower production of Brazil, the concern with the quality of the buds being intimately related with the appropriate supply of water and nutrients to the plant. With the objective of evaluating stem and bud quality the rose variety 'Osiana' was cultivated in a greenhouse using different irrigation water depths based on fractions of pan evaporation $(0.25,0.50,0.75$, 1.00 and 1.25). The experimental design consisted of total randomized blocks with five replications and five treatments. There is a linear tendency of increasing the length and diameter of the stems and the length and diameter of the buds with increasing irrigation water depths.

Key words: irrigation, evaporation, rose

\section{LÂMINAS DE IRRIGAÇÃO E A QUALIDADE DE HASTES E DE BOTÕES FLORAIS DE ROSAS CULTIVADAS EM AMBIENTE PROTEGIDO}

\begin{abstract}
RESUMO: O cultivo de rosas ocupa lugar especial na produção de flores no Brasil, onde a preocupação com a qualidade das hastes florais está intimamente relacionada com o fornecimento adequado de água e nutrientes para a planta. Este trabalho teve como objetivo avaliar a qualidade das hastes e botões florais da variedade 'Osiana' cultivada em estufa através de diferentes lâminas de irrigação determinadas à partir da fração de evaporação do tanque evaporimétrico reduzido $(0,25,0,50,0,75,1,00$ e 1,25). 0 experimento foi disposto em blocos ao acaso contendo cinco repetições e cinco tratamentos. Houve tendência linear de aumento no comprimento e diâmetro das hastes e no comprimento e diâmetro dos botões florais de acordo 0 aumento das lâminas aplicadas.
\end{abstract}

Palavras-chave: irrigação, evaporação, rosa

\section{INTRODUCTION}

Brazilian market of flowers and ornamental plants represents approximately US\$1 billion, rising $20 \%$ per year (Arruda et al., 1996).

In relation to cut flower market, in 1994 the rose represented for approximately 10 millions of dozens produced at Atibaia and Holambra cities. Rose exports represented US\$2 millions, only behind the ornamental plant seedlings (Instituto Brasileiro de Foricultura, 1997).

The consumers and mainly foreign markets require amount and quality of produced roses. Thus, it is necessary to know the most important aspects of rose production. However there is a wide use of imported technology coming from private companies by flower growers, since there is little scientific data on flower production techniques in Brazil.

The water stress symptoms in rose plants depends on its intensity and frequency. High frequency stresses can lead to curving, drying and senescence of leaves. The water stress during a large period turns the plants woody, smaller, with smaller and clearer leaves, and with a disproportion between bud and leave sizes of commercial stems (White \& Holcomb, 1987).

Caballero et al. (1996) reported that when water stress occurs during leaf growth in the marketable stem, there is an yield delay from 10 to 15 days, although it does not affect the stems quality. The most critical phase in which roses should not suffer water stress is when stems and buds have a high growth rate, which occurs during final elongation of stems and buds formation, before its opening.

Excessive soil water can also be injurious to roses by reducing soil aeration and causing an abnormal development of plants. Symptoms include yellowing, intervein chlorosis and leave drop out. In roots, generally occurs a generalized darkening (White \& Holcomb, 1987).

Evapotranspiration rate determination depends on crop, soil and atmospheric variables and evaporation rate on plant height. Soil of beds with young plants has a higher evaporation rate than that with adult plants because there are differences in the shadow caused by leaves. Transpiration rate depends on plant and atmospheric variables, as solar radiation, relative humidity, wind speed and air temperature within the greenhouse. For rose plants, the water requirements first depend on transpiration 
rate, which generally ranges from 500 to $1000 \mathrm{~g}$ of water.g dry weight ${ }^{-1}$ (White \& Holcomb, 1987).

In relation to transpiration rate, Plaut \& Zieslin (1977) studied the rose shoot wetting effects and verified that the number of harvested flowers decreased and bud average weight increased. They concluded that the direct effect of shoot wetting was a decrease in the transpiration rate of plants.

Caballero et al. (1996) measured the water consumption by rose plants cultivated in substrate and verified that it was 2.5 to $3.6 \mathrm{~mm}$ in the summer and 1.0 to $2.5 \mathrm{~mm}$ in the winter. In very hot and dry days the young leaves showed symptoms of water stress which resulted in flowers improper for marketing.

When and how much to irrigate are important questions for growers, mainly because of the increasing energy costs and lack of water resources. The rational management of irrigation is, therefore, an indispensable process in irrigated crop production (Hernandez, 1997). Crop water consumption evaluation is very important mainly in regard to the limited water resources as it is in the arid and semi-arid zones (Alves, 1996).

The methods of irrigation management can be grouped into three classes: climatic parameters, soil moisture and soil water potential measurements and in the water potential measurements of the plants. There is the conjugated method too, which is based on climatic parameters and soil conditions (Pizarro, 1996; Hernandez, 1997).

There are various methods to estimate evapotranspiration, and the Class A pan method is one of the most used, because it accounts for the integrated effects of solar radiation, wind, temperature and relative humidity on the evaporation of a free water surface. As the crop evapotranspiration depends also on these variables, the Class $A$ pan evaporation can be used to estimate potential evapotranspiration (Eto) (Doorenbos \& Pruitt, 1997; Klar, 1991).

Medeiros et al. (1997) reported that actually the Class $A$ pan has been used for irrigation management inside greenhouses but smaller pans are preferred because they occupy less space. These authors compared the evaporation of a reduced pan, with $0.6 \mathrm{~m}$ of diameter and $0.25 \mathrm{~m}$ height, and a Class A pan installed inside and outside a greenhouse. Results showed a high correlation between the two pans for both situations so that the reduced pan could be used inside greenhouses to estimate crop evapotranspiration.

The objective of this work was to evaluate the stem and bud qualities of greenhouse roses under different irrigation water depths based on reduced pan evaporation data.

\section{MATERIAL AND MÉTHODS}

Rose plants (Rosa sp.) cv. Osiana, used in this trial were approximately four years old and spaced $0.2 \mathrm{x}$
$0.3 \mathrm{~m}$, each bed containing two rows of plants. This cultivar has high productivity, straight stem with length up to $0.6 \mathrm{~m}$, stem diameter between 6 and $9 \mathrm{~mm}$ and flowers with champagne color.

The trial was carried out in a grower farm, Shimokuma Flores, at Atibaia, SP, Brazil, in the Bragança Paulista region, some $65 \mathrm{~km}$ from São Paulo city, situated at the geographical coordinates of $23^{\circ} 08^{\prime}$ S, 46을 $\mathrm{W}$ and altitude of $805 \mathrm{~m}$. This site has mean annual temperature of $19.9^{\circ} \mathrm{C}$, mean maximum and minimum temperature of 26.1 and $13.6^{\circ} \mathrm{C}$, respectively, which are ideal for rose production.

Only the applied irrigation water depth was altered. The diseases and pests control and the plants management (pruning and thinning) were carried out accordingly to the grower's program.

The experiment was installed in the third greenhouse of a block of five greenhouses disposed in North-South direction. The block occupies an area of $1250 \mathrm{~m}^{2}$ and each greenhouse $250 \mathrm{~m}^{2}$, with lateral height of $3.3 \mathrm{~m}$ and a transparent polyethylene film cover with a thickness of $0.1 \mathrm{~mm}$ supported by arcs of galvanised iron. There were lateral curtains for temperature and relative humidity control.

The drip irrigation system was composed of polyethylene hoses with $12.5 \mathrm{~mm}$ of diameter and Katiff drippers with flow rate of $2.3 \mathrm{~L} \mathrm{~h}^{-1}$ and pressure of $1 \mathrm{kgf}$ $\mathrm{cm}^{-2}$, spaced of $0.3 \mathrm{~m}$ between drippers and $1.2 \mathrm{~m}$ between lateral lines. Irrigation lines were $7 \mathrm{~m}$ long and controlled by a flow controller placed in each plot outset.

The experiment started on October 14, 1999 and finished on December 12, 1999. The greenhouse was 39 $\mathrm{m}$ long and $6.5 \mathrm{~m}$ wide which had five beds with roses. The experimental design was totally randomized blocks and each bed represented an experimental unit with five treatments and five replicates, totalizing 25 plots.

Each plot was $5.0 \mathrm{~m}$ long and $0.95 \mathrm{~m}$ wide resulting in an area of $4.75 \mathrm{~m}^{2}$ with 50 plants managed by pruning. A $2 \mathrm{~m}$ wide border was established between two adjacent plots.

Treatments were composed of different irrigation water depths, as follows: T25 - irrigation water depth corresponding to a fraction of reduced pan evaporation equal to $25 \%$; T50 - irrigation water depth corresponding to a fraction of reduced pan evaporation equal to $50 \%$; T75 - irrigation water depth corresponding to a fraction of reduced pan evaporation equal to $75 \%$; T100 irrigation water depth corresponding to a fraction of reduced pan evaporation equal to $100 \%$; T125 - irrigation water depth corresponding to a fraction of reduced pan evaporation equal to $125 \%$.

Irrigation management inside the greenhouse was performed by the evaporation of the reduced pan with diameter of $0.6 \mathrm{~m}$ and height of $0.25 \mathrm{~m}$ installed onto an wooden bench between two beds, in the middle of the greenhouse to minimize the wind effects on pan evaporation. 
Calculations of irrigation water depths were made taking into account the reduced pan water evaporation sum (Evr) between two irrigations and the "f" factor, which represents the fraction of the reduced pan evaporation depending on the treatment. The irrigation frequency was two days. Thus, irrigation water depths were calculated by:

$$
h i=E v r \times f
$$

where hi - irrigation water depth $(\mathrm{mm})$; Evr - reduced pan evaporation sum since last irrigation $(\mathrm{mm}) ; \mathrm{f}$ - fraction of reduced pan evaporation depending on the treatment. Irrigation water depths were controlled by the application time for each treatment, calculated by:

$$
T i=\frac{h_{i} \times S_{g} \times S_{l}}{q \times E_{a}}
$$

where, $\mathrm{Ti}$ - irrigation time for each treatment $(h) ; h_{i}-$ irrigation water depth to be applied for each treatment $(\mathrm{mm}) ; \mathrm{S}_{\mathrm{e}}$ - distance between drippers $(0.3 \mathrm{~m}) ; \mathrm{S}_{1}-$ distance between irrigation lines $(1.2 \mathrm{~m}) ; \mathrm{q}$ - dripper flow rate (2.3 $\left.\mathrm{L} \mathrm{h}^{-1}\right) ; \mathrm{E}_{\mathrm{a}}$ - water application efficiency $(0.95)$

As the different irrigation water depths are quantitative levels of an experimental factor, results were analysed by polynomial regression.

\section{RESULTS AND DISCUSSION}

The observed average values of stem lengths, stem diameters, bud lengths and bud diameters for each treatment are presented in TABLE 1.

Application of irrigation water depths began before the pruning of stems that would be evaluated. Thus, the sprouts and stems development began under the influence of irrigation water depth applied.

Obtained stem length average values were fitted to linear regression and the different irrigation water depths had significative effects on this variable accordingly to $\mathrm{F}$ test (Figure 1 ). The stem length average values ranged from $63.38 \mathrm{~cm}$ to $71.57 \mathrm{~cm}$ and were higher than $60.0 \mathrm{~cm}$ in all plots.

TABLE 1 - Observed average values of stems length (S.L.), stems diameter (S.D.), buds length (B.L.) and

\begin{tabular}{|c|c|c|c|c|c|}
\hline $\begin{array}{c}\text { Treatment } \\
\mathrm{f}\end{array}$ & $\begin{array}{c}\text { Water } \\
\text { depth } \\
\text { applied }\end{array}$ & S.L. & S.D. & B.L. & B.D. \\
\hline & $\mathrm{mm}$ & \multicolumn{4}{|c|}{ - } \\
\hline T25 & 44.5 & 63.38 & 0.626 & 4.52 & 2.523 \\
\hline $\mathrm{T} 50$ & 89.1 & 65.79 & 0.617 & 4.61 & 2.556 \\
\hline T75 & 133.6 & 66.73 & 0.627 & 4.58 & 2.630 \\
\hline T100 & 178.2 & 71.57 & 0.637 & 4.75 & 2.608 \\
\hline T125 & 222.7 & 70.09 & 0.676 & 4.78 & 2.667 \\
\hline \multirow[t]{2}{*}{ Test F } & Linear & $0.00004^{*}$ & $0.00807^{\star}$ & $0.00246^{*}$ & $0.04912^{*}$ \\
\hline & Quadratic & $0.27999^{*}$ & $0.05689^{*}$ & $0.71164^{*}$ & $0.81482^{*}$ \\
\hline
\end{tabular}
buds diameter (B.D.) and values of test $F$.

* Significative at 0,05 of probability by test $F$.
The stem classification was made accordingly to their lengths. Stems with 40,50 and $60-70 \mathrm{~cm}$ are classified as short, medium and long, respectively, and higher prices are obtained for the longest.

It was observed that stems longer than $60.0 \mathrm{~cm}$ are feature of the "Osiana" cultivar. However, application of irrigation water depths below plant demand for long periods may decrease stem lengths, reducing quality and consequently the market acceptance.

These results show a relationship between stem length and irrigation water depth (Figure 1). ChimonidouPavlidou (1998), working with roses cultivated in pots, observed that applying the same irrigation water depth determined by Class $A$ pan evaporation with different irrigation intervals $(0,2,3$ and 6 days) during 9 months, the stem lengths were significantly lower when irrigation intervals were 6 days, during summer.

Although sprouting began under the different water depths effects, stem lengths for T25 were statistically equal to the other treatments. Nevertheless, stems length for T50, T75, T100 and T125 were 3.8, 5.3, 12.3 and $10.6 \%$ higher than for T25, respectively. Chimonidou-Pavlidou (1996) observed in his trial that stem and bud length and bud diameter decreased when water stress occurred in the beginning of sprouting. When water stress was applied in other plant development stages no significative effect was observed.

Stem diameter also had a significative linear increase with the irrigation water depth, with a determination coefficient of 0.67 (Figure 2). Average values are shown in TABLE 1. Stem diameter were 0.62 , $0.62,0.63,0.64$ and $0.67 \mathrm{~cm}$ for T25, T50, T75, T100 and T125, respectively, which represents an increase of 3.2 and $8.0 \%$ for $\mathrm{T} 100$ and $\mathrm{T} 125$, respectively, in relation to T25. Urban et al. (1996) reported that in plants well water supplied, the cells have greater growth, which results in higher stem diameter and plant height.

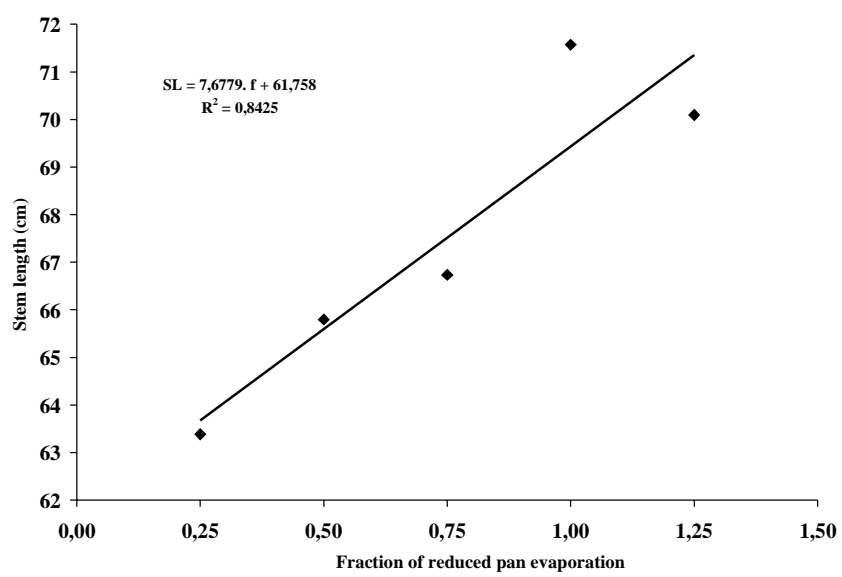

Figure 1 - Relation between the fraction of reduced pan evaporation and stem length of roses, cv. 'Osiana'. 


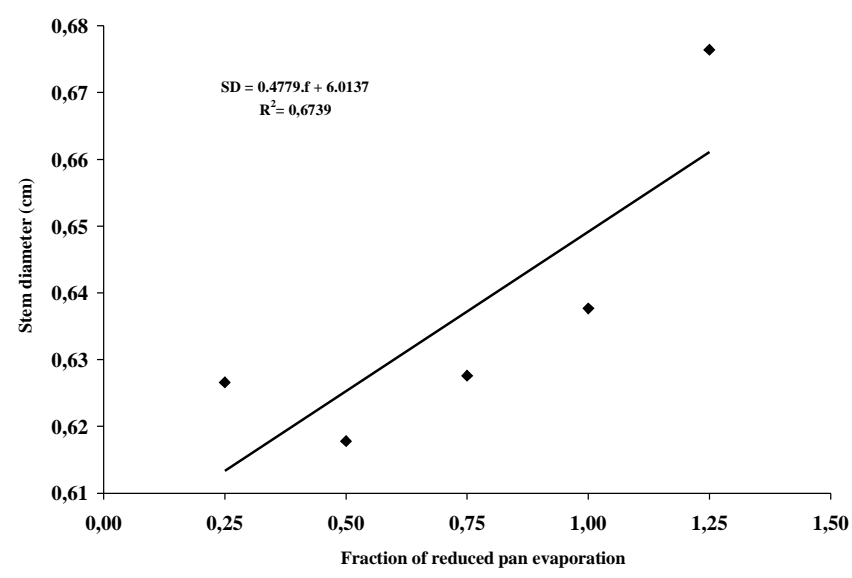

Figure 2 - Relation between the fraction of reduced pan evaporation and stem diameter of roses, cv. "Osiana".

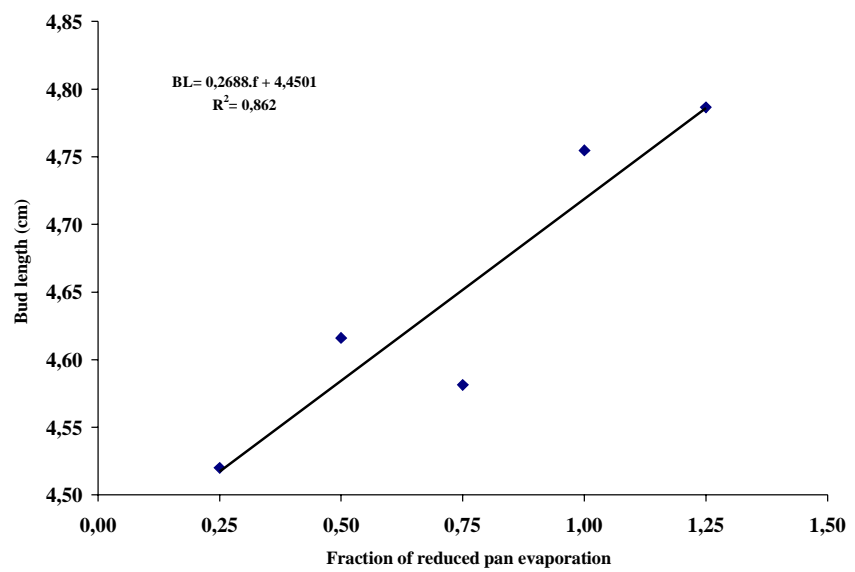

Figure 3 - Relation between the fraction of reduced pan evaporation and bud length of roses, cv. "Osiana".

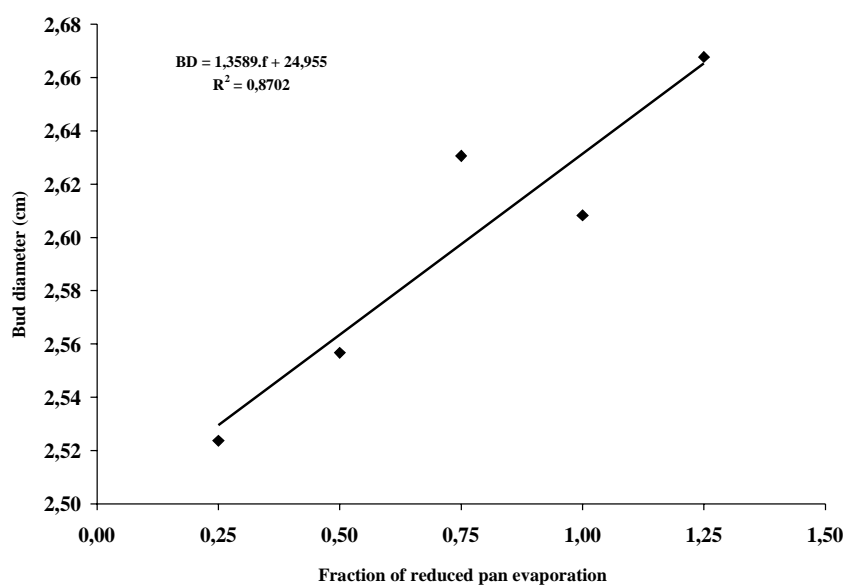

Figure 4 - Relation between the fraction of reduced pan evaporation and bud diameter of roses, cv. "Osiana".

The average values of stem diameter for all treatments were higher than $0.60 \mathrm{~cm}$. This diameter provides high quality stems with higher durability after harvest, which increases market acceptance and selling price.
Bud length and diameter were significantly affected by different irrigation water depths, increasing both linearly with water depth.

Bud length average values were 4.52, 4.61, 4.58, 4.75 and $4.78 \mathrm{~cm}$ for T25, T50, T75, T100 and T125, respectively, representing an increase of $5.8 \%$ for $\mathrm{T} 125$ in relation to T25 (TABLE 1). Figure 3 shows the relation between bud length and the fraction of reduced pan evaporation with a determination factor equal to 0.87 .

Regression analysis for bud diameter showed that this variable increased linearly with water depth applied, with an $r^{2}=0.87$ (Figure 4). The observed average values showed an increase of $5.95 \%$ for $\mathrm{T} 125$ in relation to T25 (TABLE 1).

\section{REFERENCES}

ALVES, D.R.B.; KLAR, A.E. Comparação de métodos para estimar evapotranspiração de referência em túnel de plástico. Irriga, v.1, p.26-34, 1996.

ARRUDA, S.T.; OLIVETTE, M.P.A.; CASTRO, C.E.F. Diagnóstico da floricultura do Estado de São Paulo. Revista Brasileira de Horticultura Ornamental, v.2, p.1-18, 1996.

CABALLERO, M.; MANSITO, P.; ZIESLIN, N. Water use and crop productivity of roses growing on volcanic lapilli(Picon) in Canary Islands. Acta Horticulturae, n.424, p.41-44, 1996.

CHIMONIDOU-PAVLIDOU, D. Yield and quality of rose 'Madelon' as affected by four irrigation and three shading regimes. Acta Horticulturae, n.458, p.95-102, 1998.

DOORENBOS, J.; PRUITT, W.O. Necessidades hídricas das culturas. Campina Grande: UFPB, 1997. 204p.

HERNANDEZ, F.B.T. Manejo da irrigação em fruteiras. http:/ /www.agr.feis.unesp.br/fruteiras. (14 Nov.1999)

INSTITUTO BRASILEIRO DE FLORICULTURA. Boletim Ibraflor. Campinas: IBRAFLOR, 1997. 96p.

KLAR, A.E. Irrigação: frequência e quantidade de aplicação. São Paulo: Nobel, 1991. 156p.

MEDEIROS, J.F.; PEREIRA, F.A.C.; FOLEGATTI, M.V.; PEREIRA, A.R.; VILLA NOVA, N.A. Comparação entre evaporação em tanque classe A padrão e em minitanque, instalados em estufa e estação meteorológica. In: CONGRESSO BRASILEIRO DE AGROMETEOROLOGIA, Piracicaba, 1997. Anais. Piracicaba: Sociedade Brasileira de Agrometeorologia, 1997. p.228-230.

PIZARRO, F.C. Riegos localizados de alta frecuencia: goteo, microaspersion, exudacion. 3.ed. Madrid: Mundi-Prensa, 1996. 513p.

PLAUT, Z.; ZIESLIN, N. The effect of canopy wetting on plant water status, $\mathrm{CO}_{2}$ fixation, ion content and growth rate of 'Baccara' roses. Physiologia Plantarum, n.39, p.317-322, 1977.

URBAN, L. Effect of high-pressure mist and daytime continuous $\mathrm{CO} 2$ enrichment on leaf difusive conductance of Rosa hybrida plants growth on rockwool. Acta Horticulturae, n.361, p.317-324, 1994.

WHITE, J.W.; HOLCOMB, E.J. Water requirement and irrigation practices. In: WHITE, J.W.; HOLCOMB, E.J. A manual of greenhouse rose production. Ithaca: Roses incorporated, 1987. 375p.

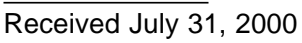

